\title{
Short Communication: Identification of Allelic Variation at the Bovine DRA Locus by Polymerase Chain Reaction-Single Strand Conformational Polymorphism
}

\author{
H. Zhou, J. G. H. Hickford, ${ }^{1}$ Q. Fang, and S. O. Byun \\ Gene-Marker Laboratory, Cell Biology Group, Agriculture, and Life Sciences Division, PO Box 84, Lincoln University, \\ Lincoln 7647, New Zealand
}

\begin{abstract}
The major histocompatibility complex $D R A$ locus is noteworthy among the major histocompatibility complex class II loci for the little or no variation reported in many species. In cattle, $D R A$ has not been investigated in depth, and the extent of variation at the locus is not yet known. In this study, we used PCR-single strand conformational polymorphism (SSCP) analysis to screen for potential sequence variation in the second exon of bovine $D R A$, which encodes the antigen-presentation groove. Four unique SSCP patterns were detected among 384 cattle from New Zealand. Sequence analysis revealed that these SSCP patterns represent $4 D R A$ alleles; and 3 single nucleotide polymorphisms were detected in exon 2 . However, all of the single nucleotide polymorphisms were synonymous, and no amino acid change was therefore expected in this region. The polymorphism detected may be linked to variation elsewhere in the gene that affects its structure or function. Key words: cattle, $D R A$ locus, polymorphism, polymerase chain reaction-single strand conformational polymorphism
\end{abstract}

The major histocompatibility complex (MHC) class II molecules are cell-surface glycol proteins that are comprised of noncovalently linked $\alpha$ and $\beta$ chains. These molecules bind antigen peptides and present them to $\mathrm{T}$ lymphocytes for immune recognition and hence play a pivotal role in the initiation of specific immune responses to exogenous antigens. In dairy cattle, there is evidence that certain MHC class II haplotypes are associated with genetic resistance against mastitis (Kelm et al., 1997; Sharif et al., 1998) and bovine leukemia virus infection (Xu et al., 1993; Zanotti et al., 1996).

Received September 6, 2006.

Accepted November 22, 2006.

${ }^{1}$ Corresponding author: Hickford@lincoln.ac.nz
To investigate the role of $\mathrm{MHC}$ genes in immune responsiveness, it is important to have a better understanding of the natural occurrence of MHC polymorphism.

In cattle, there are 2 expressed groups of $\mathrm{MHC}$ class II receptors, DQ and DR. For DQ, the $\alpha$ and $\beta$ chainencoding genes are highly polymorphic and duplicated in some individual animals, creating extensive diversity for the DQ molecule (Sigurdardottir et al., 1992; Gelhaus et al., 1995; Ballingall et al., 1997). For DR, only one $\alpha$-chain gene (DRA) was identified, and only one $\beta$-chain gene (DRB3) is known to be functional in cattle (Groenen et al., 1990; Ellis and Ballingall, 1999). Although DRB3 is highly polymorphic, only one sequence has been reported for bovine DRA, despite earlier work that identified RFLP variants (Andersson et al., 1986). As sequence variation has not been reported, the bovine $D R A$ gene is thought to be monomorphic (Ellis and Ballingall, 1999). However, this may not be true, especially as $D R A$ has not been well studied in cattle, and in sheep the homologue has 3 alleles identified by Southern hybridization (Escayg et al., 1993). Although DRA appears to be highly conserved in most mammalian species (Chu et al., 1994; Yuhki and O’Brien, 1997; Smith et al., 2005), polymorphism has been observed in equids (Brown et al., 2004), rhesus macaques (de Groot et al., 2004), and water buffalo (Sena et al., 2003). In this study, we used PCR-single strand conformational polymorphism (SSCP) analysis to examine bovine $D R A$ to ascertain whether polymorphism existed at this locus, which may be important in the context of the associations described above between MHC variation and susceptibility to disease in dairy cattle.

Three hundred and eighty-four cattle from $10 \mathrm{New}$ Zealand farms were investigated, and blood samples from these animals were collected on FTA cards (Whatman, Middlesex, UK). Genomic DNA was purified from the blood using a 2-step washing procedure (Zhou et al., 2006).

Two PCR primers were designed based on the published bovine DRA sequence (GenBank accession num- 
ber M30120; van der Poel et al., 1990) to amplify the entire exon 2 sequence. These primers were $D R A$-up ( $5^{\prime}$ TCTTCCTCTCCTGGTTCCCAC- ${ }^{\prime}$ ), which was located in the $3^{\prime}$ end of intron 1 , and DRA-dn (5'-GCTACAAT TCCCAAGTCTAGG- $3^{\prime}$ ), located in the $5^{\prime}$ end of intron 2. Primers were synthesized by Proligo (Boulder, CO). Amplification was performed in a $20-\mu \mathrm{L}$ reaction containing genomic DNA on one 1.2-mm disc of washed FTA paper, $0.25 \mu M$ of each primer, $150 \mu M$ of each dNTP (Eppendorf, Hamburg, Germany), $2.5 \mathrm{~m} M$ of $\mathrm{Mg}^{2+}, 0.5 \mathrm{U}$ of Taq DNA polymerase (Qiagen, Hilden, Germany), and $1 \times$ the reaction buffer supplied. The thermal profile consisted of $2 \mathrm{~min}$ at $94^{\circ} \mathrm{C}$, followed by 35 cycles of $30 \mathrm{~s}$ at $94^{\circ} \mathrm{C}, 30 \mathrm{~s}$ at $60^{\circ} \mathrm{C}$, and $30 \mathrm{~s}$ at $72^{\circ} \mathrm{C}$, with a final extension of $5 \mathrm{~min}$ at $72^{\circ} \mathrm{C}$. Amplification was carried out in an iCycler (Bio-Rad Laboratories, Hercules, CA). Amplicons with the expected size of 333 bp were visualized by transillumination at $254 \mathrm{~nm}$ following electrophoresis at $5 \mathrm{~V} / \mathrm{cm}$ for $30 \mathrm{~min}$ in $1 \%$ agarose (Quantum Scientific, Queensland, Australia) gels, using $1 \times$ Tris-borate-EDTA (TBE) buffer ( $89 \mathrm{~m} M$ Tris, $89 \mathrm{~m} M$ boric acid, $2 \mathrm{~m} M \mathrm{Na}_{2}$ EDTA) containing $200 \mathrm{ng} /$ $\mathrm{mL}$ of ethidium bromide.

To screen for allelic variants of the $D R A$ gene, all amplicons were subjected to SSCP analysis. A $0.7-\mu \mathrm{L}$ aliquot of each amplicon was mixed with $7 \mu \mathrm{L}$ of loading dye (98\% formamide, $10 \mathrm{mM}$ EDTA, $0.025 \%$ bromophenol blue, $0.025 \%$ xylene-cyanol). After denaturation at $95^{\circ} \mathrm{C}$ for $5 \mathrm{~min}$, samples were cooled rapidly on wet ice and then loaded on $16 \times 18 \mathrm{~cm}, 14 \%$ acrylamide:bisacrylamide (37.5:1; Bio-Rad Laboratories) gels. Electrophoresis was performed in Protean II xi cells (Bio-Rad Laboratories), at $320 \mathrm{~V}$ for $18 \mathrm{~h}$ at $12^{\circ} \mathrm{C}$ in $0.5 \times \mathrm{TBE}$ buffer. Gels were silver-stained according to the method of Sanguinetti et al. (1994). Under the established conditions, 4 unique SSCP binding patterns were resolved, with one or a combination of 2 of these patterns being observed for individual cattle (Figure 1). This was consistent with there being homozygous or heterozygous genotypes at the DRA locus.

To determine the nucleotide sequences corresponding to individual SSCP patterns, genomic DNA representatives of these unique SSCP patterns were selected for amplification using the proofreading enzyme Pwo SuperYield DNA polymerase (Roche Applied Science, Mannheim, Germany), and the amplicons were subsequently ligated into the $\mathrm{pCR} 4$ Blunt-TOPO vector (Invitrogen, Carlsbad, CA). A $2-\mu \mathrm{L}$ aliquot of the ligation mixture was used to transform competent Escherichia coli cells (One Shot INV $\alpha \mathrm{F}^{\prime}$, Invitrogen). Between 10 and 15 insert-positive colonies for each transformation were picked and incubated overnight in Terrific broth (Invitrogen) at $37^{\circ} \mathrm{C}$, in a shaking rotary incubator $(225$

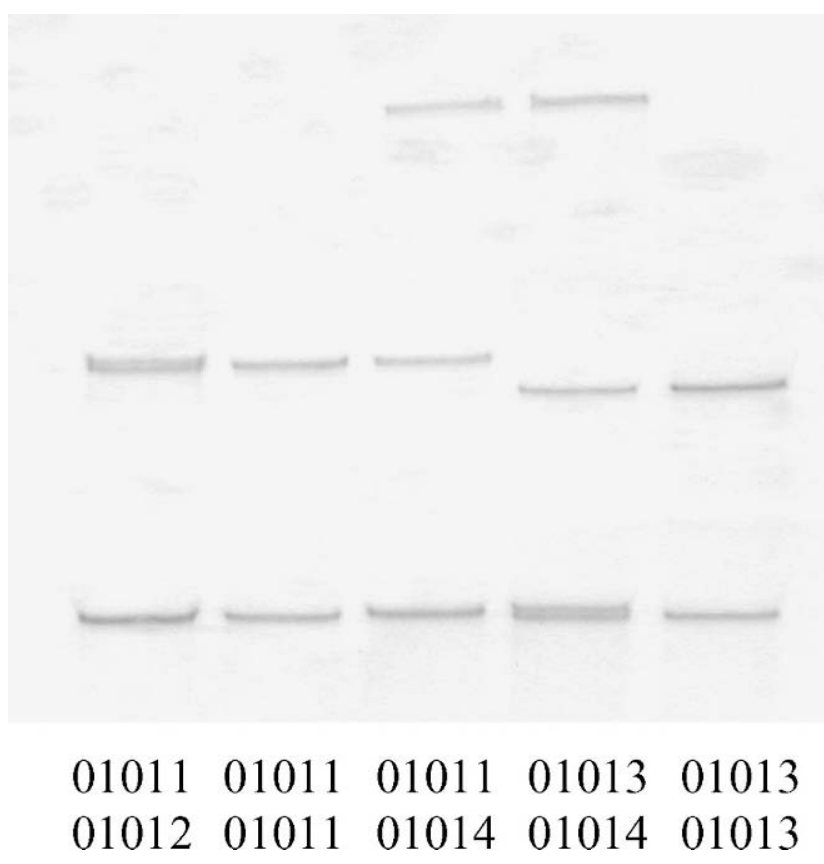

Figure 1. The PCR-single-strand conformational polymorphism of the bovine $D R A$ gene. Representative genotypes for the 4 unique SSCP patterns corresponding to 4 allelic sequences *01011, *01012, *01013, and *01014 (GenBank accession nos. DQ821713, DQ821714, DQ821715, and DQ821716, respectively) are shown.

rpm). Plasmid DNA was recovered from bacterial cells by boiling for $10 \mathrm{~min}$ in $0.8 \%$ Triton X-100 solution, and $1 \mu \mathrm{L}$ of the supernatant was used as a template for PCR under the conditions described previously. Amplimers from clones and the corresponding genomic DNA were run adjacent to each other on SSCP gels for comparison of the banding patterns, and only those clones for which the patterns matched those of the corresponding genomic DNA templates were selected for DNA extraction and subsequent DNA sequencing.

Plasmid DNA was extracted from overnight cultures using a QIAprep Spin Miniprep kit (Qiagen). The DNA was sequenced in both directions using the M13-forward and reverse primers at the Waikato DNA Sequencing Facility (University of Waikato, Hamilton, New Zealand). Identical sequences obtained from at least 3 separate clones from different animals, or 2 independent PCR amplifications from the same animal, were subjected to further sequence analysis. Sequence analysis was carried out using DNAMAN (Version 4.0, Lynnon BioSoft, Vaudreuil, Canada) and revealed 4 different nucleotide sequences. One sequence was identical to the published bovine DRA sequence, whereas the remaining 3 sequences were novel but shared high 
Table 1. Bovine DRA allelic variation detected in exon 2

\begin{tabular}{lccccc}
\hline \multirow{2}{*}{$\begin{array}{l}\text { Nucleotide } \\
\text { position }^{1}\end{array}$} & $\begin{array}{c}\text { Single } \\
\text { nucleotide } \\
\text { polymorphism }\end{array}$ & $* 01011^{2}$ & $* 01012$ & $* 01013$ & $* 01014$ \\
\cline { 3 - 6 } & $\mathrm{C} / \mathrm{T}$ & $\mathrm{C}$ & $\mathrm{T}$ & $\mathrm{C}$ & $\mathrm{C}$ \\
116 & $\mathrm{G} / \mathrm{A}$ & $\mathrm{G}$ & $\mathrm{G}$ & $\mathrm{G}$ & $\mathrm{A}$ \\
197 & $\mathrm{C} / \mathrm{T}$ & $\mathrm{C}$ & $\mathrm{C}$ & $\mathrm{T}$ & $\mathrm{C}$ \\
& Frequency $(\mathrm{n}=384)$ & 0.64 & 0.03 & 0.24 & 0.09 \\
\hline
\end{tabular}

${ }^{1}$ Nucleotide positions are relative to the first nucleotide of exon 2 of the bovine DRA gene.

${ }^{2}$ Identical to the published bovine DRA sequence M30120 (van der Poel et al., 1990).

sequence homology to the known bovine $D R A$ sequence. This suggests that these sequences represent allelic variants of the bovine $D R A$ gene.

Sequence alignment showed there were 3 single nucleotide polymorphisms (SNP) in the bovine DRA exon 2 region, which creates 4 alleles in total (Table 1). The bovine $D R A$ allele sequences detected here were named as $* 01011, * 01012, * 01013$, and $* 01014$ according to the BoLA allele nomenclature (Davies et al., 1997; http:// www.projects.roslin.ac.uk/bola/bolahome.html), and deposited into the NCBI GenBank with the accession numbers DQ821713 to DQ821716.

All of these SNP were synonymous, and no amino acid polymorphism was predicted in the $\alpha 1$ domain of the bovine DRA molecule. However, the functional significance of these SNP cannot be ignored because it has been reported that synonymous mutations in coding regions may act alone or in combination with other mutations in the same transcript to influence mRNA stability and translation, thereby causing functional effects (Duan et al., 2003). Additionally the SNP may be linked to variation in other $D R A$ gene regions with functional or structural significance. Alternatively, the lack of polymorphism at the amino acid level may be as a result of critical structural or functional constraints in the exon 2 region (Chu et al., 1994).

\section{ACKNOWLEDGMENTS}

This work was financially supported by the GeneMarker Laboratory, Lincoln University, New Zealand.

\section{REFERENCES}

Andersson, L., J. Bohme, P. A. Peterson, and L. Rask. 1986. Genomic hybridization of bovine class II major histocompatibility genes: 2. Polymorphism of DR genes and linkage disequilibrium in the DQ-DR region. Anim. Genet. 17:295-304.

Ballingall, K. T., A. Luyai, and D. J. McKeever. 1997. Analysis of genetic diversity at the DQA loci in African cattle: Evidence for a BoLA-DQA3 locus. Immunogenetics 46:237-244.

Brown, J. J., W. Thomson, P. Clegg, S. Eyre, L. J. Kennedy, J. Matthews, S. Carter, and W. E. Ollier. 2004. Polymorphisms of the equine major histocompatibility complex class II DRA locus. Tissue Antigens 64:173-179.
Chu, Z. T., C. Carswell-Crumpton, B. C. Cole, and P. P. Jones. 1994. The minimal polymorphism of class II E $\alpha$ chains is not due to the functional neutrality of mutations. Immunogenetics 40:9-20.

Davies, C. J., L. Andersson, S. A. Ellis, E. L. Hensen, H. A. Lewin, S. Mikko, N. E. Muggli-Cockett, J. J. van der Poel, and G. C. Russell. 1997. Nomenclature for factors of the BoLA system, 1996. Report of the ISAG BoLA Nomenclature Committee. Anim. Genet. 28:159-168.

de Groot, N., G. G. Doxiadis, N. G. De Groot, N. Otting, C. Heijmans, A. J. Rouweler, and R. E. Bontrop. 2004. Genetic makeup of the DR region in rhesus macaques: Gene content, transcripts, and pseudogenes. J. Immunol. 172:6152-6157.

Duan, J., M. S. Wainwright, J. M. Comeron, N. Saitou, A. R. Sanders, J. Gelernter, and P. V. Gejman. 2003. Synonymous mutations in the human dopamine receptor D2 (DRD2) affect mRNA stability and synthesis of the receptor. Hum. Mol. Genet. 12:205-216.

Ellis, S. A., and K. T. Ballingall. 1999. Cattle MHC: Evolution in action? Immunol. Rev. 167:159-168.

Escayg, A. P., G. W. Montgomery, J. G. Hickford, and D. W. Bullock. 1993. A BglII RFLP at the ovine MHC class II DRA locus. Anim. Genet. 24:217.

Gelhaus, A., C. Wippern, D. Mehlitz, and R. D. Horstmann. 1995. Sequence polymorphism of BoLA-DQA. Immunogenetics 42:296-298.

Groenen, M. A., J. J. van der Poel, R. J. Dijkhof, and M. J. Giphart. 1990. The nucleotide sequence of bovine MHC class II $D Q B$ and $D R B$ genes. Immunogenetics 31:37-44.

Kelm, S. C., J. C. Detilleux, A. E. Freeman, M. E. Kehrli, Jr., A. B. Dietz, L. K. Fox, J. E. Butler, I. Kasckovics, and D. H. Kelley. 1997. Genetic association between parameters of inmate immunity and measures of mastitis in periparturient Holstein cattle. J. Dairy Sci. 80:1767-1775.

Sanguinetti, C. J., E. Dias Neto, and A. J. Simpson. 1994. Rapid silver staining and recovery of PCR products separated on polyacrylamide gels. BioTechniques 17:914-921.

Sena, L., M. P. Schneider, B. Brenig, R. L. Honeycutt, J. E. Womack, and L. C. Skow. 2003. Polymorphisms in MHC-DRA and -DRB alleles of water buffalo (Bubalus bubalis) reveal different features from cattle $D R$ alleles. Anim. Genet. 34:1-10.

Sharif, S., B. A. Mallard, B. N. Wilkie, J. M. Sargeant, H. M. Scott, J. C. Dekkers, and K. E. Leslie. 1998. Associations of the bovine major histocompatibility complex DRB3 (BoLA-DRB3) alleles with occurrence of disease and milk somatic cell score in Canadian dairy cattle. Anim. Genet. 29:185-193.

Sigurdardottir, S., C. Borsch, K. Gustafsson, and L. Andersson. 1992. Gene duplications and sequence polymorphism of bovine class II $D Q B$ genes. Immunogenetics 35:205-213.

Smith, D. M., J. K. Lunney, C. S. Ho, G. W. Martens, A. Ando, J. H. Lee, L. Schook, C. Renard, and P. Chardon. 2005. Nomenclature for factors of the swine leukocyte antigen class II system, 2005. Tissue Antigens 66:623-639.

van der Poel, J. J., M. A. Groenen, R. J. Dijkhof, D. Ruyter, and M. J. Giphart. 1990. The nucleotide sequence of the bovine MHC class II alpha genes: $D R A, D O A$, and DYA. Immunogenetics 31:29-36.

Xu, A., M. J. van Eijk, C. Park, and H. A. Lewin. 1993. Polymorphism in BoLA-DRB3 exon 2 correlates with resistance to persistent 
lymphocytosis caused by bovine leukaemia virus. J. Immunol. 151:6977-6985.

Yuhki, N., and S. J. O'Brien. 1997. Nature and origin of polymorphism in feline MHC class II DRA and DRB genes. J. Immunol. 158:2822-2833.

Zanotti, M., G. Poli, W. Ponti, M. Polli, M. Rocchi, E. Bolzani, M. Longeri, S. Russo, H. A. Lewin, and M. J. van Eijk. 1996. Associa- tion of BoLA class II haplotypes with subclinical progression of bovine leukaemia virus infection in Holstein-Friesian cattle. Anim. Genet. 27:337-341.

Zhou, H., J. G. H. Hickford, and Q. Fang. 2006. A two-step procedure for extracting genomic DNA from dried blood spots on filter paper for polymerase chain reaction amplification. Anal. Biochem. 354:159-161. 